\title{
The Impact of Management Practices on Soil Fertility and Foliar Nutrient Concentrations in a Spruce (Picea abies Link) Forest Ecosystem of Rodopi Mountainous Area, in Northern Greece
}

\author{
Evgenia PAPAIOANNOU, Theocharis CHATZISTATHIS*, \\ Georgios MENEXES
}

\author{
Aristotle University of Thessaloniki, School of Agriculture, Forestry and Natural Environment, 54124 Thessaloniki, \\ Greece; eapapaioa@agro.auth.gr; chchatzi@in.gr(*0rrespondingauthor); gemenexes@agro.auth.gr
}

\begin{abstract}
After forest harvesting, organic matter accumulation and soil nutrient availability are usually negatively influenced, especially during the first years. The hypothesis that 15 years after selective harvesting $(15 \mathrm{Y})$ the increased forest biomass, together with the enhanced nutrient recycling rates, compared to 5-years after harvesting (5Y), could restore nutrient availability and organic $\mathrm{C}$ accumulation (both in forest floor and soil) to similar levels to the intact site, was tested. The aim of this study was to investigate the effect of the timing of management practices (intact forest-control, 5Y, 15Y) on organic matter content, nutrient concentrations in needles, forest floor and soil, in a forest ecosystem of Picea abies L., in Rodopi mountainous area, in northern Greece. Significant differences between the intact site and the other two treatments were found in: i) soil N, P, C/N and exchangeable Ca, ii) organic matter and nutrient accumulation (basically in the upper $30 \mathrm{~cm}$ ), iii) foliar $\mathrm{K}, \mathrm{Fe}$ and $\mathrm{Zn}$ concentrations. In conclusion: i) forest management practices clearly influenced soil fertility and organic matter accumulation, ii) 15 years after selective harvesting nutrient and organic $\mathrm{C}$ accumulation in forest floor, as well as $\mathrm{K}$ and Fe accumulation in soil were restored to similar levels to the intact sites; thus, our hypothesis was partially correct.
\end{abstract}

Keywords: forest biomass, forest floor, forest management, nutrient accumulation, nutrient recycling, organic matter

\section{Introduction}

Natural forests present high biological polymorphism due to the heterogeneity of their structure and composition. The way the management practices of forest ecosystems carried out during the last decades has led to the reduction of the abundance of silvicultural species (Lindenmayer and Franklin, 2002). The vegetation of natural and artificial forest ecosystems constitute one of the most important long-term pools of soil $\mathrm{C}$ and nutrients. Forest degradation may disturb the cycle of C (Vande Walle et al., 2001); thus, organic $\mathrm{C}$ accumulation in soils may be disturbed due to the limited production of organic residues and to the higher degree of their decomposition (Dirham, 1998). During the last years, after the changes in the methods of forest management, the increase of restoration practices, together with the abandonment for cultivation of many hilly, eroded lands (converted from old forestlands to croplands many years ago), forest sites were often experienced substantial increases of soil organic $\mathrm{C}$ and nutrient pools (Papaioannou et al., 2016).
The storage of organic $\mathrm{C}$ in soils from mixed pine forests was influenced by soil depth, texture, microclimate and site area (Dilustro et al., 2005). Forest management practices, forest vegetation and fires, as well as other physical disasters played a crucial role in soil erosion, thus in the balance of organic carbon (Johnson et al., 2002; Lal, 2005; MataixSolera et al., 2011; Cerda et al., 2017; Pereira et al., 2017). Depending on silvicultural management practices and on the methods of collection of forest products, soils were positively or negatively influenced by $\mathrm{C}$ accumulation or decrease, respectively (Laiho et al., 2003; Peltoniemi et al., 2004; McLaughlin and Phillips, 2006). It was found that soil $\mathrm{C}$ reduced during the first 10 years after management practices (Knoepp and Swank, 1997; Mendham et al., 2003). In addition, the removal of whole trees caused shortterm losses of soil C (Johnson and Curtis, 2001; Laiho et al., 2003). However, long-term effects of harvesting on soil organic C storage were not detected (Johnson et al., 2002; McLaughlin and Phillips, 2006).

Forest ecosystems were greatly influenced by human activities, and especially by unsuccessful management 
302

practices. For example, the use of tractors in recent years in order to remove timber from forests increased soil degradation, like compaction. In addition, soil degradation also occurred when higher wood volume was removed, than this provided in the management plan. Only a small number of forests were submitted to limited management practices, while most were unmanaged. All these management practices leaded to changes in structure and diversity of forest ecosystems. Soil nutrient availability and organic C content were among the first parameters negatively influenced by unsuccessful forest management practices. The important influence of severe disturbance, such as clear cutting (or intensive site preparation) on nutrient recycling and nutritional status of forests was discussed in the papers of Bartsch (2000) and Merino et al. (2004). Moreover, since after harvesting forest biomass was significantly decreased (Herbohn and Congdon, 1998) and increased surface run-off usually took place (due to canopy opening), organic $\mathrm{C}$ accumulation and soil nutrient availability were negatively influenced during the first years after harvesting. However, information about the effect of harvesting time (short- and long-term effects) on soil C storage, fertility and foliar nutrient concentrations is clearly lacking from literature. Harvesting in agricultural fields also had several impacts, such as soil compaction and erosion, while there is also a lack of information on soil C storage (Rodrigo Comino et al., 2015, 2017).

The hypothesis that 15 years after selective harvesting the increased forest biomass, together with the enhanced nutrient recycling rates, compared to the $5 \mathrm{Y}$ treatment, could restore nutrient availability and organic $\mathrm{C}$ accumulation (both in forest floor and soil) to similar levels to the intact site, was tested. Thus, the objective of our study was to investigate the influence of timing of selective harvesting (5 and 15 years after its implementation, in a triple comparison among $5 \mathrm{Y}, 15 \mathrm{Y}$ and intact site) on C storage and accumulation, soil fertility and foliar nutrient concentrations in Picea abies L. plantations.

\section{Materials and Methods}

\section{Description of the study area and forest management practices}

The criterion for the selection of the study area was the extended presence of Picea abies plantations with different timing of management practices (selective harvesting 5 and 15 years ago), in places with similar physiographic (altitude and slope inclination) and soil characteristics with the adjacent virgin forest of Fraktos, Drama (41 32' 01.41" N \& $24^{\circ} 29^{\prime} 12.13$ ” E), Northeastern Greece (Fig. 1). The coordinates of the other two experimental surface areas (selective harvesting 5 and 15 years ago) were $41^{\circ} 30^{\prime} 44.68^{\prime \prime}$ $\mathrm{N} \& 24^{\circ} 30^{\prime} 07.83^{\prime \prime} \mathrm{E}$, and $41^{\circ} 31^{\prime} 13.77^{\prime \prime} \mathrm{N} \& 24^{\circ} 29^{\prime}$ 10.82 " E, respectively. The main forest vegetation of the area consisted of Pinus nigra, Pinus sylvestris and Picea abies plantations. The parent material of that soil was biotitic granodiorite. The soils in the area of Fraktos were moderately acid, while they had an average depth of 25-45 $\mathrm{cm}$ and high stoniness. Values of $\mathrm{pH}$ varied from 4.49 to 5.29. The climate of this region could be characterized as transitional from Mediterranean to middle Europeancontinental, despite the fact that it accepts many rainfalls during the summer period (Mauromatis, 1980).
Forest management practices in this region consisted of the following characteristics: i) Rotation between two selective harvests was 10 years, ii) the quantity harvested every 10 years varied from 8 to $15 \%$ of the total forest area (depending on cluster productivity), iii) the wood harvested from these clusters was used either as building material, or for the construction of electricity pillars. In the intact forest, the mean height of the 5 tallest trees was $29.0 \mathrm{~m}$ and their mean diameter was $42.0 \mathrm{~cm}$. In the 15-year and 5-year treatments the corresponding values were $27.0 \mathrm{~m}$ and 38.0 $\mathrm{cm}$, and $26.0 \mathrm{~m}$ and $37.0 \mathrm{~cm}$, respectively. In each tree, the diameter at breast height $(\mathrm{DBH})$ was measured with a diameter tape. Subsequently, the basal area was calculated from $\mathrm{DBH}$. As far as the tree height measurement is concerned, the Haga instrument was used.

\section{Soil, forest floor and leaf sampling}

Soils were taken in July and sampled at depth intervals of $0-5,5-10,10-30$ and $30-50 \mathrm{~cm}$. In each of the three treatments (virgin forest, forest sites selectively harvested 5 years and 15 years ago), 5 sites (plots) (of $314 \mathrm{~m}^{2}$ each) were included for soil sampling. In each site, one soil profile was included for sampling. Sampling at rocky or disturbed locations was avoided. If sampling at a randomly selected location was not suitable, it was conducted $0.5 \mathrm{~m}$ in each of the cardinal directions (in the order: north, south, east, west), until a suitable sampling location was encountered.

In three sampling points per site (plot), the depth of the organic layer was measured and manually extracted a litter sample. Forest floor sampling was realized by pressing a 625 $\mathrm{cm}^{2}$ steel sheet sampling frame $(10 \mathrm{~cm}$ deep) into the forest floor and by collecting all the organic material above the mineral soil. After sampling, the horizon $A_{o}(L)$ was separated from $A_{o}(F H)$ in each of the 3 sampling points, selected for every forest site. The 3 sampling points per site were randomly selected. Mineral soil was removed after successive sieving and the organic material was oven-dried in $84{ }^{\circ} \mathrm{C}$ for $48 \mathrm{~h}$. Then, a small quantity of the organic material was milled to a fine powder for chemical analyses.

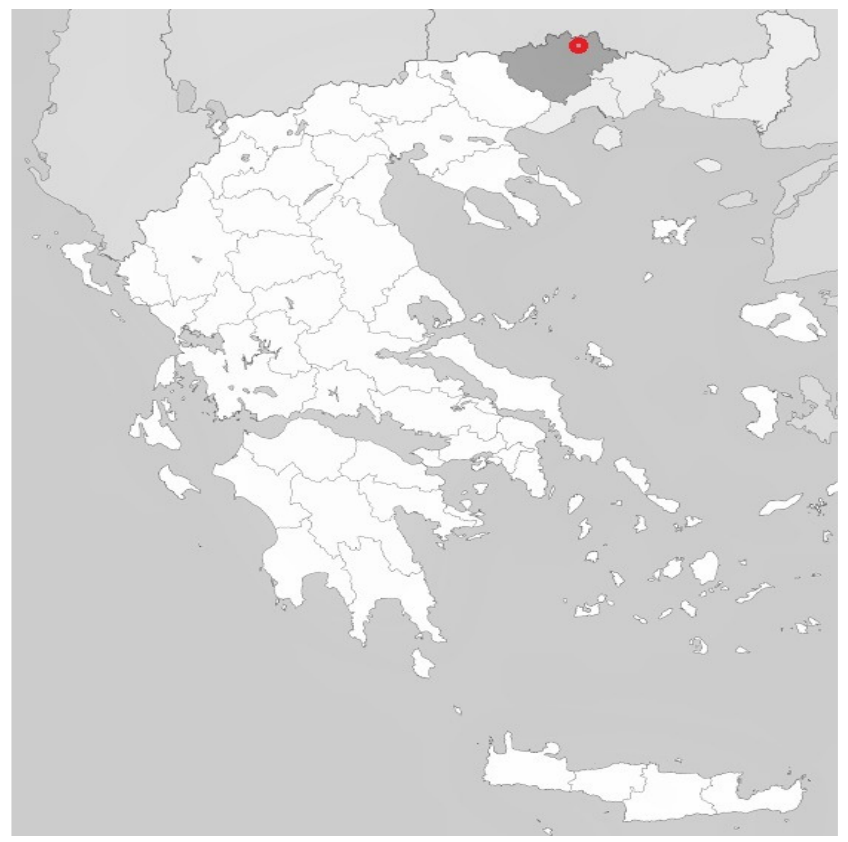

Fig. 1. Map of the study area in Drama (NE Greece) 
Finally, in each of the 5 selected forest sites per treatment, 10 composite samples of green needles of Picea abies, from the upper $1 / 3$ of the trees' canopy, were randomly selected in July, in order to determine the nutrient statues of Picea abies plantations.

\section{for soil \\ Laboratory chemical analyses and nutrient determination}

Soil samples were air-dried, gravels were removed, and afterwards sieved to pass a 10 mesh screen (Soil-test, INC. U.S.A. Standard Testing Sieve $2 \mathrm{~mm}-10 \mathrm{mesh}$ ) before analyses. All the roots were removed from the sieve. General chemical analyses, as well as the extraction of micronutrients were conducted. General chemical analyses included $\mathrm{pH}$ measurement, as well as the determination of: i) organic C, ii) exchangeable cation concentrations ( $\mathrm{Ca}, \mathrm{Mg}, \mathrm{K}$ and $\mathrm{Na}$ ), iii) extractable $\mathrm{P}$, iv) total $\mathrm{N}$. More specifically, $\mathrm{pH}$ measurement was conducted electrometrically, in a soil: distilled water solution (1:1) (Bates, 1964; McLean, 1982), the organic $\mathrm{C}$ was determined according to the $\mathrm{K}_{2} \mathrm{Cr}_{2} \mathrm{O}_{7}$ method (Allison, 1965; Nelson and Sommers, 1982) and then, the organic matter was calculated by multiplying soil organic $\mathrm{C}$ with 1.724 . Total $\mathrm{N}$ was determined according to the Kjeldahl method (Stevenson, 1982), while the determination of available $\mathrm{P}$ was conducted with the use of $0.5 \mathrm{~N} \mathrm{NaHCO}$ at $\mathrm{pH} 8.5$; it was afterwards measured spectophotometrically (Olsen and Sommers, 1982). The concentrations of the exchangeable cations were determined with atomic absorption spectroscopy, after the extraction of $10 \mathrm{~g}$ soil with $\mathrm{CH}_{3} \mathrm{COONH}_{4}$ solution $1 \mathrm{~N}, \mathrm{pH} 7.0$ (Grant, 1982). Micronutrient concentrations ( $\mathrm{Fe}, \mathrm{Mn}, \mathrm{Zn}$ and $\mathrm{Cu}$ ) were also determined with atomic absorption spectroscopy (Perkin-Elmer 2380 Waltham, MA, USA), after the extraction of $10 \mathrm{~g}$ soil with DTPA solution, $\mathrm{pH} 7.3$ (Lindsay and Norvell, 1978).

Finally, in order to calculate the organic matter content and nutrient quantities (in $\mathrm{kg} / \mathrm{ha}$ ), the bulk density (in $\left.\mathrm{g} / \mathrm{cm}^{3}\right)$ per soil layer was used; then, the concentrations were multiplied with bulk density and the accumulation was calculated. More specifically, for the surface forest soil layers bulk density usually varies from 0.7 to $1.0 \mathrm{~g} / \mathrm{cm}^{3}$, while in deeper soil layers bulk density varies from 1.0 to $1.35 \mathrm{~g} / \mathrm{cm}^{3}$ (Alifragis, 2010).

Laboratory chemical analyses and nutrient determination for litter and needles

A quantity of $0.5 \mathrm{~g}$ of the milled fine powder of each sample from litter and from needles was dry-ashed in a muffle furnace at $515^{\circ} \mathrm{C}$ for 5 hours; then, the ash was dissolved with a mixture of $\mathrm{HNO}_{3}+\mathrm{HClO}_{4}+\mathrm{H}_{2} \mathrm{SO}_{4}$ (5:1:0.5, in $200{ }^{\circ} \mathrm{C}$ ) (Allen et al., 1986). Phosphorus was determined colorimetrically, by using the phosphomolybdenum blue method (Alifragis, 2010), while $\mathrm{Ca}, \mathrm{Mg}, \mathrm{Na}, \mathrm{K}, \mathrm{Fe}, \mathrm{Mn}, \mathrm{Cu}$, and $\mathrm{Zn}$ concentrations were determined with atomic absorption spectroscopy (PerkinElmer 2380 Waltham, MA, USA). Finally, total $\mathrm{N}$ was determined by the Kjeldahl method (Stevenson, 1982).

\section{Statistical analysis}

Soil analyses data were analyzed within the methodlogical frame of Mixed Linear Models, with the ANOVA method. The proposed model involved two fixed effects factors, in a split-plot arrangement: one factor between experimental units, i.e. "Forest Treatments" with 3 levels (Intact forest, forest subjected to selective harvesting 15 years ago and forest subjected to selective harvesting 5 years ago), and one within experimental units, with repeated measures, i.e. factor "soil depth" with 4 levels $(0-5,5-10,10$ 30 and $30-50 \mathrm{~cm}$ ). Forest treatments were considered as main plots and soil depths were the sub-plots. There were five sites (replications) per forest treatment. The basic experimental design was the Completely Randomized Design (CRD). In this model the sites were considered as random effects factor, nested within the forest treatments. Data from forest floor analyses were analyzed according to the same model, with the exception that there were three random sampling points per site (plot). The measured values of the three sampling points were averaged prior to the ANOVA. The ANOVA method was mainly performed in order to compute the appropriate standard errors for the comparisons of treatments' mean values. Comparisons of mean values were done according to the Least Significant Difference (LSD) criterion at significance level $a=0.05$. All statistical analyses were accomplished with the SPSS v15.0 statistical software.

\section{Results}

\section{Mineral soil chemical properties}

Table 1 shows that forest management practices negatively influenced soil $\mathrm{N}$ and organic matter (OM) (in deeper soil layers), as well as the ratio $\mathrm{C} / \mathrm{N}$ and the exchangeable $\mathrm{Ca}$. In addition, significant differences between the control (intact forest) and the other two treatments (selective harvesting 5 and 15 years ago) were found with regard to extractable concentrations of micronutrients $(\mathrm{Cu}, \mathrm{Zn}, \mathrm{Fe}$ and $\mathrm{Mn})$. High fluctuations were observed in $\mathrm{Mn}$ (from 3.69 to $46.18 \mathrm{mg} / \mathrm{kg}$ ), $\mathrm{Zn}$ (from 0.06 to $9.25 \mathrm{mg} / \mathrm{kg}$ ), Fe (from 21.53 to $107.57 \mathrm{mg} / \mathrm{kg}$ ) and $\mathrm{Cu}$ concentrations (from 0.04 to $0.42 \mathrm{mg} / \mathrm{kg}$ ), depending on forest treatment and soil depth. Finally, pH values were within the normal levels for a typical forest soil, varying from 4.49 to 5.28 , and they were not significantly affected by the forest management practices (Table 1 ).

Table 2 shows organic matter content and nutrient accumulation in the soil layer $0-50 \mathrm{~cm}$. Significant differences were found between the undisturbed forest site and the 15-year treatment, with regard to organic matter content and $\mathrm{N}, \mathrm{P} \mathrm{Ca}, \mathrm{Mn}$ and $\mathrm{Zn}$ accumulation. In contrast, insignificant differences were recorded between the forest treatments in $\mathrm{Fe}, \mathrm{Cu}$ and $\mathrm{Na}$ accumulation.

\section{Forest floor (litter)}

From Table 3, which shows the organic matter and nutrient concentrations in the forest floor horizons $\left(\mathrm{A}_{\circ \mathrm{o}}\right.$ and $\mathrm{A}_{\mathrm{o}}$ ), it is concluded that significant differences (basically in the $\mathrm{A}_{\mathrm{oo}}$ horizon) were recorded for $\mathrm{Ca}, \mathrm{Na}, \mathrm{Fe}, \mathrm{Cu}, \mathrm{Mn}$ and $\mathrm{Zn}$ concentrations between the control and the other two treatments. Nutrient concentrations in the forest floor decreased in the order $\mathrm{N}>\mathrm{Ca}>\mathrm{Fe}>\mathrm{K}>\mathrm{Mg}>\mathrm{Mn}>\mathrm{P}>\mathrm{Zn}>\mathrm{Cu}$ (Table 3).

Finally, with regard to organic matter and nutrient accumulation in the forest floor horizons $\left(\mathrm{A}_{\circ \circ}\right.$ and $\left.A_{\circ}\right)$, 
Table 1. Chemical properties in the four $(0-5 ; 5-10 ; 10-30 ; 30-50 \mathrm{~cm})$ soil layers among the 3 treatments (undisturbed forest, 15 years ago selective cutting and 5 years ago selective cutting) (OM=Organic matter)

\begin{tabular}{|c|c|c|c|c|c|c|c|c|c|c|c|c|c|}
\hline \multirow{2}{*}{ Parameter } & \multicolumn{4}{|c|}{ Undisturbed forest } & \multicolumn{4}{|c|}{15 years ago selective cutting } & \multicolumn{4}{|c|}{5 years ago selective cutting } & \multirow{2}{*}{$\mathrm{LSD}_{0.05}$} \\
\hline & $0-5$ & $5-10$ & $10-30$ & $30-50$ & $0-5$ & $5-10$ & $10-30$ & $30-50$ & $0-5$ & $5-10$ & $10-30$ & $30-50$ & \\
\hline $\mathrm{pH}$ & $4.65 b$ & $4.72 b$ & $4.83 \mathrm{ab}$ & $4.96 \mathrm{ab}$ & $4.49 b$ & $4.82 \mathrm{ab}$ & $5.19 \mathrm{a}$ & $5.28 \mathrm{a}$ & $4.73 b$ & $4.99 \mathrm{ab}$ & $5.17 \mathrm{a}$ & $5.26 \mathrm{a}$ & 0.45 \\
\hline $\mathrm{OM}(\%)$ & $16.40 \mathrm{a}$ & $14.60 \mathrm{ab}$ & $11.25 b$ & $7.06 c$ & $15.15 \mathrm{a}$ & $10.68 \mathrm{bc}$ & $7.00 \mathrm{c}$ & $4.32 \mathrm{~d}$ & $17.64 \mathrm{a}$ & $12.29 b$ & $6.71 \mathrm{c}$ & $5.64 \mathrm{~cd}$ & 2.25 \\
\hline $\mathrm{N}(\%)$ & $0.73 \mathrm{a}$ & $0.67 \mathrm{ab}$ & $0.51 b$ & $0.41 b$ & $0.43 b$ & $0.34 \mathrm{c}$ & $0.23 \mathrm{~cd}$ & $0.17 \mathrm{~d}$ & $0.52 b$ & $0.44 b$ & $0.24 \mathrm{~cd}$ & $0.27 \mathrm{~cd}$ & 0.16 \\
\hline $\mathrm{C} / \mathrm{N}$ & $14.36 b$ & $13.97 \mathrm{bc}$ & $14.50 \mathrm{~b}$ & $11.22 \mathrm{c}$ & $20.44 \mathrm{a}$ & $18.47 \mathrm{a}$ & $18.31 \mathrm{a}$ & $14.55 b$ & $20.77 \mathrm{a}$ & $17.34 \mathrm{ab}$ & $16.05 \mathrm{ab}$ & $12.16 \mathrm{c}$ & 4.88 \\
\hline $\mathrm{P}(\mathrm{mg} / 100 \mathrm{~g})$ & $1.60 \mathrm{a}$ & $1.30 \mathrm{ab}$ & $0.89 \mathrm{~b}$ & $0.65 b c$ & $1.22 \mathrm{~b}$ & $0.89 \mathrm{~b}$ & $0.61 b c$ & $0.48 c$ & $0.93 b$ & $0.75 b c$ & $0.59 \mathrm{c}$ & $0.54 c$ & 0.33 \\
\hline $\begin{array}{c}\mathrm{Ca} \\
(\mathrm{meq} / 100 \mathrm{~g})\end{array}$ & $10.58 \mathrm{a}$ & $7.30 \mathrm{~b}$ & $4.70 c$ & $2.46 \mathrm{~d}$ & $4.43 c$ & $3.63 \mathrm{~cd}$ & $3.07 \mathrm{~cd}$ & $1.96 \mathrm{~d}$ & $8.30 \mathrm{a}$ & $5.54 b$ & $3.27 \mathrm{~cd}$ & $2.68 \mathrm{~d}$ & 1.97 \\
\hline $\begin{array}{c}\mathrm{Mg} \\
(\mathrm{meq} / 100 \mathrm{~g})\end{array}$ & $1.48 \mathrm{a}$ & $1.15 \mathrm{ab}$ & $0.71 b c$ & $0.46 c$ & $1.09 \mathrm{ab}$ & $0.91 b$ & $0.90 \mathrm{~b}$ & $0.70 \mathrm{bc}$ & $1.98 \mathrm{a}$ & $1.54 \mathrm{a}$ & $1.13 \mathrm{ab}$ & $1.04 \mathrm{~b}$ & 0.55 \\
\hline $\begin{array}{c}\mathrm{K} \\
(\mathrm{meq} / 100 \mathrm{~g})\end{array}$ & $0.79 \mathrm{a}$ & $0.60 \mathrm{a}$ & $0.38 \mathrm{~b}$ & $0.34 \mathrm{~b}$ & $0.68 \mathrm{a}$ & $0.58 \mathrm{a}$ & $0.51 \mathrm{ab}$ & $0.53 \mathrm{ab}$ & $0.59 a$ & $0.39 \mathrm{~b}$ & $0.29 \mathrm{bc}$ & $0.26 \mathrm{c}$ & 0.11 \\
\hline $\begin{array}{c}\mathrm{Na} \\
(\mathrm{meq} / 100 \mathrm{~g})\end{array}$ & $0.14 \mathrm{a}$ & $0.10 \mathrm{ab}$ & $0.09 \mathrm{~b}$ & $0.09 \mathrm{~b}$ & $0.10 \mathrm{ab}$ & $0.07 \mathrm{bc}$ & $0.07 b c$ & $0.08 \mathrm{~b}$ & $0.06 \mathrm{c}$ & $0.06 \mathrm{c}$ & $0.07 \mathrm{bc}$ & $0.08 b$ & 0.03 \\
\hline $\mathrm{Fe}(\mathrm{mg} / \mathrm{kg})$ & $69.10 \mathrm{~b}$ & $89.91 \mathrm{ab}$ & $66.43 b$ & $45.64 c$ & $107.57 \mathrm{a}$ & $90.42 \mathrm{ab}$ & $45.54 \mathrm{c}$ & $25.33 \mathrm{~d}$ & $105.96 \mathrm{a}$ & $79.93 b$ & $38.58 \mathrm{~cd}$ & $21.53 \mathrm{~d}$ & 20.02 \\
\hline $\mathrm{Cu}(\mathrm{mg} / \mathrm{kg})$ & $0.42 \mathrm{a}$ & $0.33 b$ & $0.16 c$ & $0.09 \mathrm{de}$ & $0.27 \mathrm{~b}$ & $0.17 \mathrm{c}$ & $0.08 \mathrm{de}$ & $0.13 \mathrm{~cd}$ & $0.12 \mathrm{~cd}$ & $0.07 \mathrm{de}$ & $0.04 \mathrm{e}$ & $0.28 b$ & 0.06 \\
\hline $\mathrm{Mn}(\mathrm{mg} / \mathrm{kg})$ & $46.18 \mathrm{a}$ & $45.43 a$ & $25.15 b$ & $8.83 \mathrm{~d}$ & $23.21 \mathrm{~b}$ & $18.27 \mathrm{bc}$ & $9.37 \mathrm{~d}$ & $3.69 \mathrm{e}$ & $42.63 \mathrm{a}$ & $14.46 \mathrm{~cd}$ & $9.24 \mathrm{~d}$ & $7.67 \mathrm{~d}$ & 7.65 \\
\hline $\mathrm{Zn}(\mathrm{mg} / \mathrm{kg})$ & $9.25 \mathrm{a}$ & $6.20 \mathrm{~b}$ & $1.82 \mathrm{~d}$ & $0.43 \mathrm{f}$ & $2.14 \mathrm{c}$ & $0.76 \mathrm{e}$ & $0.28 \mathrm{fg}$ & $0.06 \mathrm{~g}$ & $2.49 c$ & $0.41 \mathrm{f}$ & $0.28 \mathrm{fg}$ & $0.12 \mathrm{~g}$ & 0.27 \\
\hline
\end{tabular}

Mean values in the same row followed by different letters are statistically significant different among the treatments and the soil layers, according to the LSD criterion, for $P<0.05$.

Table 2. Organic matter $(\mathrm{OM})$ content and nutrient $(\mathrm{kg} / \mathrm{ha})$ accumulation in soil $(0-50 \mathrm{~cm})$

\begin{tabular}{ccccc}
\hline Parameter & Undisturbed forest & 15 years ago selective cutting & 5 years ago selective cutting & LSD $_{0.05}$ \\
\hline $\mathrm{OM}$ & $508495 \mathrm{a}$ & $385144 \mathrm{~b}$ & $442268 \mathrm{ab}$ & 7776 \\
$\mathrm{~N}$ & $25075 \mathrm{a}$ & $12963 \mathrm{~b}$ & $17015 \mathrm{ab}$ & 8902 \\
$\mathrm{P}$ & $44 \mathrm{a}$ & $35 \mathrm{~b}$ & $35 \mathrm{~b}$ & 5 \\
$\mathrm{Ca}$ & $4396 \mathrm{a}$ & $3164 \mathrm{~b}$ & $4214 \mathrm{ab}$ & 633 \\
$\mathrm{Mg}$ & $423 \mathrm{~b}$ & $579 \mathrm{ab}$ & $846 \mathrm{a}$ & 303 \\
$\mathrm{~K}$ & $805 \mathrm{ab}$ & $1204 \mathrm{a}$ & $706 \mathrm{~b}$ & 411 \\
$\mathrm{Na}$ & $107 \mathrm{a}$ & $101 \mathrm{a}$ & $97 \mathrm{a}$ & 25 \\
$\mathrm{Fe}$ & $301 \mathrm{a}$ & $234 \mathrm{a}$ & 76 \\
$\mathrm{Cu}$ & $0.82 \mathrm{a}$ & $0.88 \mathrm{a}$ & 0.2 \\
$\mathrm{Mn}$ & $107 \mathrm{a}$ & $0.69 \mathrm{a}$ & $68 \mathrm{~b}$ & 25 \\
$\mathrm{Zn}$ & $11.0 \mathrm{a}$ & $49 \mathrm{~b}$ & $2.3 \mathrm{~b}$ & 1 \\
\hline
\end{tabular}

Mean values in the same row followed by different letters are statistically significant different among the treatments, according to the LSD criterion, for $P<0.05$

Table 3. Organic matter $(\mathrm{OM})$ and nutrient concentrations in the forest floor

\begin{tabular}{ccccccccc}
\hline \multirow{2}{*}{ Parameter } & \multicolumn{2}{c}{ Undisturbed forest } & \multicolumn{2}{c}{15 years ago selective cutting } & \multicolumn{2}{c}{5 years ago selective cutting } & \multirow{2}{*}{ LSD } \\
\cline { 2 - 5 } & $\mathrm{A}_{\circ}$ & $\mathrm{A}_{\circ}$ & $\mathrm{A}_{\circ}$ & $\mathrm{A}_{\circ}$ & $\mathrm{A}_{\circ}$ & $\mathrm{A}_{\circ}$ & \\
\hline $\mathrm{OM}(\%)$ & $86.45 \mathrm{a}$ & $48.7 \mathrm{~b}$ & $88.75 \mathrm{a}$ & $68.81 \mathrm{ab}$ & $87.32 \mathrm{a}$ & $72.50 \mathrm{ab}$ & 25.15 \\
$\mathrm{~N}(\%)$ & $1.27 \mathrm{a}$ & $1.08 \mathrm{a}$ & $1.09 \mathrm{a}$ & $1.21 \mathrm{a}$ & $1.12 \mathrm{a}$ & $1.38 \mathrm{a}$ & 0.39 \\
$\mathrm{P}(\mathrm{mg} / \mathrm{g})$ & $0.62 \mathrm{a}$ & $0.58 \mathrm{a}$ & $0.64 \mathrm{a}$ & $0.70 \mathrm{a}$ & $0.57 \mathrm{a}$ & $0.63 \mathrm{a}$ & 0.16 \\
$\mathrm{Ca}(\mathrm{mg} / \mathrm{g})$ & $9.19 \mathrm{a}$ & $2.10 \mathrm{~b}$ & $8.1 \mathrm{a}$ & $1.96 \mathrm{~b}$ & $7.49 \mathrm{a}$ & $3.15 \mathrm{~b}$ & 1.95 \\
$\mathrm{Mg}(\mathrm{mg} / \mathrm{g})$ & $0.98 \mathrm{~b}$ & $1.58 \mathrm{a}$ & $0.95 \mathrm{~b}$ & $1.46 \mathrm{a}$ & $0.83 \mathrm{~b}$ & $1.29 \mathrm{ab}$ & 0.48 \\
$\mathrm{~K}(\mathrm{mg} / \mathrm{g})$ & $1.11 \mathrm{a}$ & $1.54 \mathrm{a}$ & $1.24 \mathrm{a}$ & $1.55 \mathrm{a}$ & $1.30 \mathrm{a}$ & $1.41 \mathrm{a}$ & 0.46 \\
$\mathrm{Na}(\mathrm{mg} / \mathrm{g})$ & $0.12 \mathrm{a}$ & $0.12 \mathrm{a}$ & $0.07 \mathrm{~b}$ & $0.09 \mathrm{ab}$ & $0.09 \mathrm{ab}$ & $0.07 \mathrm{~b}$ & 0.03 \\
$\mathrm{Fe}(\mathrm{mg} / \mathrm{kg})$ & $1346 \mathrm{~b}$ & $4810 \mathrm{a}$ & $1657 \mathrm{~b}$ & $4194 \mathrm{a}$ & $1805 \mathrm{~b}$ & $4055 \mathrm{a}$ & 916 \\
$\mathrm{Cu}(\mathrm{mg} / \mathrm{kg})$ & $8 \mathrm{~b}$ & $11 \mathrm{a}$ & $6 \mathrm{bc}$ & $10 \mathrm{ab}$ & $5 \mathrm{c}$ & $11 \mathrm{a}$ & 2 \\
$\mathrm{Mn}(\mathrm{mg} / \mathrm{kg})$ & $854 \mathrm{c}$ & $1388 \mathrm{a}$ & $1124 \mathrm{ab}$ & $1208 \mathrm{a}$ & $878 \mathrm{bc}$ & $1244 \mathrm{a}$ & 276 \\
$\mathrm{Zn}(\mathrm{mg} / \mathrm{kg})$ & $49 \mathrm{bc}$ & $73 \mathrm{a}$ & $40 \mathrm{c}$ & $57 \mathrm{~b}$ & $43 \mathrm{c}$ & $63 \mathrm{a}$ & 12 \\
\hline
\end{tabular}

Mean values in the same row followed by different letters are statistically significant different among the treatments and the forest floor horizons, according to the LSD criterion, for $P<0.05$

significant differences between the undisturbed forest and the two treated sites were recorded for almost all nutrients (Table 4). With the exception of $\mathrm{Ca}, \mathrm{Na}$ and $\mathrm{Zn}$, the accumulation of all the other nutrients, in both forest floor horizons, were higher in the 15-year treatment. In addition, organic matter accumulation was also significantly higher in the same treatment (Table 4).

\section{Foliar nutrient concentrations}

With regard to foliar nutrient concentrations, significant differences among the three forest treatments were recorded only for $\mathrm{K}, \mathrm{Fe}$ and $\mathrm{Zn}$ concentrations 
Table 4. Organic matter content and nutrient $(\mathrm{kg} / \mathrm{ha})$ accumulation in the forest floor $\left(\mathrm{A}_{\mathrm{oo}}+\mathrm{A}_{\mathrm{o}}\right)$

\begin{tabular}{|c|c|c|c|c|}
\hline Parameter & Undisturbed forest & 15 years ago selective cutting & 5 years ago selective cutting & $\mathrm{LSD}_{0.05}$ \\
\hline OM & $39045 b$ & $57905 a$ & $37737 b$ & 648 \\
\hline $\mathrm{N}$ & $774 \mathrm{ab}$ & $985 a$ & $683 b$ & 266 \\
\hline $\mathrm{P}$ & $40 \mathrm{ab}$ & $58 a$ & $31 \mathrm{~b}$ & 21 \\
\hline $\mathrm{Ca}$ & $250 \mathrm{a}$ & $215 a$ & $212 \mathrm{a}$ & 56 \\
\hline $\mathrm{Mg}$ & $99 a$ & $108 \mathrm{a}$ & $62 \mathrm{~b}$ & 25 \\
\hline K & $99 \mathrm{ab}$ & $124 a$ & $70 \mathrm{~b}$ & 30 \\
\hline $\mathrm{Na}$ & $8 a$ & $7 a$ & $4 \mathrm{~b}$ & 2 \\
\hline $\mathrm{Fe}$ & $274 a b$ & $320 \mathrm{a}$ & $189 \mathrm{~b}$ & 89 \\
\hline $\mathrm{Cu}$ & $0.72 \mathrm{ab}$ & $0.79 a$ & $0.53 b$ & 0.22 \\
\hline $\mathrm{Mn}$ & $87 \mathrm{ab}$ & $98 \mathrm{a}$ & $68 \mathrm{~b}$ & 21 \\
\hline $\mathrm{Zn}$ & $4.80 \mathrm{a}$ & $4.50 \mathrm{a}$ & $3.20 \mathrm{~b}$ & 0.58 \\
\hline
\end{tabular}

Mean values in the same row followed by different letters are statistically significant different among the treatments, according to the LSD criterion, for $P<0.05$

Table 5. Nutrient concentrations of needles

\begin{tabular}{ccccc}
\hline Parameter & Undisturbed forest & 15 years ago selective cutting & 5 years ago selective cutting & LSD $_{0.05}$ \\
\hline $\mathrm{N}(\%)$ & $1.30 \mathrm{a}$ & $1.01 \mathrm{a}$ & $1.05 \mathrm{a}$ & 0.34 \\
$\mathrm{P}(\mathrm{g} / \mathrm{kg})$ & $0.94 \mathrm{a}$ & $0.92 \mathrm{a}$ & $0.79 \mathrm{a}$ & 0.18 \\
$\mathrm{Ca}(\mathrm{g} / \mathrm{kg})$ & $6.26 \mathrm{a}$ & $6.04 \mathrm{a}$ & $7.83 \mathrm{a}$ & 1.88 \\
$\mathrm{Mg}(\mathrm{g} / \mathrm{kg})$ & $0.69 \mathrm{a}$ & $0.72 \mathrm{a}$ & $0.71 \mathrm{a}$ & 0.14 \\
$\mathrm{~K}(\mathrm{~g} / \mathrm{kg})$ & $3.68 \mathrm{~b}$ & $4.46 \mathrm{~b}$ & $5.97 \mathrm{a}$ & 1.02 \\
$\mathrm{Na}(\mathrm{g} / \mathrm{kg})$ & $0.04 \mathrm{a}$ & $0.04 \mathrm{a}$ & $0.05 \mathrm{a}$ & 0.01 \\
$\mathrm{Fe}(\mathrm{mg} / \mathrm{kg})$ & $80 \mathrm{~b}$ & $78 \mathrm{~b}$ & $111 \mathrm{a}$ & 19 \\
$\mathrm{Cu}(\mathrm{mg} / \mathrm{kg})$ & $0.72 \mathrm{a}$ & $0.66 \mathrm{a}$ & 0.23 \\
$\mathrm{Mn}(\mathrm{mg} / \mathrm{kg})$ & $687 \mathrm{a}$ & $658 \mathrm{a}$ & $662 \mathrm{a}$ & 124 \\
$\mathrm{Zn}(\mathrm{mg} / \mathrm{kg})$ & $28 \mathrm{a}$ & $19 \mathrm{~b}$ & $26 \mathrm{~b}$ & 5 \\
\hline
\end{tabular}

Mean values in the same row followed by different letters are statistically significant different among the treatments, according to the LSD criterion, for $P<0.05$

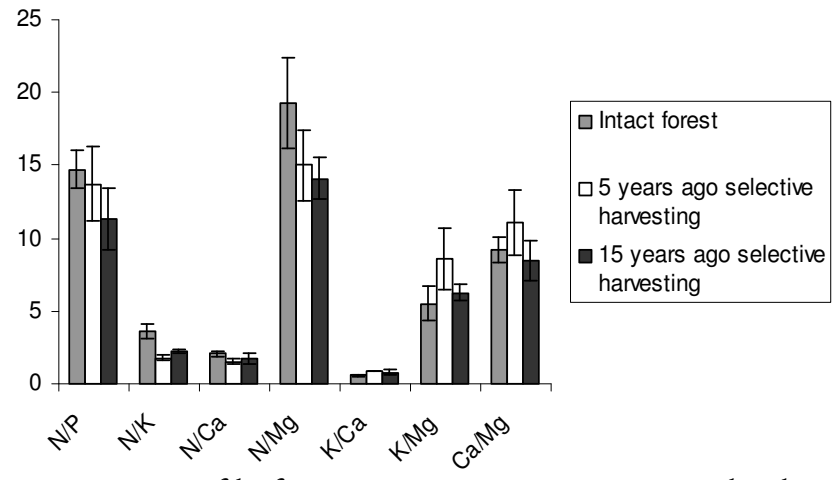

Fig. 2. Ratios of leaf nutrient concentrations among the three forest treatments. Vertical error bars correspond to standard deviations

(significantly higher leaf $\mathrm{K}$ and $\mathrm{Fe}$ concentrations were found in the 5-year treatment) (Table 5). Very high levels of $\mathrm{Mn}(>650 \mathrm{mg} / \mathrm{kg}$ d.w.) were recorded in all the 3 treatments studied; however, no toxicity symptoms were found. All the other nutrient concentrations were within the normal levels of sufficiency or adequacy (Table 5). Nutrient ratios $\mathrm{N} / \mathrm{K}, \mathrm{N} / \mathrm{Ca}, \mathrm{N} / \mathrm{Mg}$ and $\mathrm{K} / \mathrm{Ca}$ significantly differed between the intact and the two treated sites (Fig. 2).

\section{Discussion}

From Table 1 it is concluded that soil organic matter and $\mathrm{N}$, as well as the ratio $\mathrm{C} / \mathrm{N}$ significantly differed between the control site (intact forest) and the other two treatments (selective harvesting 5 and 15 years ago). Covelo and Gallardo (2002) found that the clear cutting of Pinus pinaster plantations reduced by $30 \%$ the soil available $\mathrm{N}$ on the harvested sites, but no differences in the inorganic and organic soil P was detected. In our study, significant differences in the extractable $\mathrm{P}$ were recorded only between the intact site and the 5-year treatment, especially at the surface soil layers (Table 1). McGrath et al. (2001) found that, 6 years after clearing in an Amazonian forest, extractable inorganic $\mathrm{P}$ was $30-50 \%$ lower in an agro-forest soil, suggesting that $\mathrm{P}$ uptake by the aggrading ecosystem exceeded its restoration in soil solution by other $\mathrm{P}$ pools. It seems possible that, in our study, the significant differences in extractable P only between the intact site and the 5-year treatment (and not between the control site and the 15-year treatment) might be probably ascribed to the decrease of $\mathrm{P}$ losses and to the restoration of soil P pools due to biomass increase 15 years after the selective harvesting ( $\mathrm{P}$ pool was probably enhanced through nutrient recycling). In contrast, 5 years after selective harvesting $P$ losses were high.

Organic matter (in deeper soil layers) and $\mathrm{N}$ were significantly higher in the control site, than in the other two treatments. The $\mathrm{C} / \mathrm{N}$ ratio increased (due to the higher decline of soil $\mathrm{N}$, compared to organic $\mathrm{C}$ ) after selective harvesting (Table 1), something which agrees with the data of Covelo and Gallardo (2002). According to the same authors, the higher values of the ratio $\mathrm{C} / \mathrm{N}$ found in the harvested, compared to the intact sites, indicated differential losses of $\mathrm{N}$ versus $\mathrm{C}$ after disturbance. A significant decrease in soil organic $\mathrm{C}$, three years after an intensive shelterwood 
306

cut in the first $5 \mathrm{~cm}$ of the mineral soil, in Nothofagus pumilio forests of the Chilean Patagonia, was also found by Klein et al. (2008). However, according to the same authors, slightly higher $\mathrm{C}$ contents were observed in the upper horizons of the mineral soil 8 and 14 years after the intensive forest cut. Their applied shelterwood system appeared to generate only short-term losses of soil organic $\mathrm{C}$, and regeneration identified as one of the most important factors influencing soil organic $\mathrm{C}$ in their study (Klein et al., 2008).

In our study, although soil organic matter content in the upper $10 \mathrm{~cm}$ was not influenced by forest management, its content in deeper layers $(10-30$ and $30-50 \mathrm{~cm}) 5$ and 15 years after selective harvesting was significantly decreased, compared to the intact site (Table 1). It seems that organic matter content of deeper soil layers was not recovered to the initial (before selective harvesting) levels. Mendham et al. (2003) found that soil organic C decreased mostly in the first 10 years after intervention. While tree harvesting may cause short-term losses in soil organic C (Laiho et al., 2003), negative long-term effects on soil organic $\mathrm{C}$ storage were not detected (Johnson et al., 2002; McLaughlin and Phillipps, 2006). Finally, in the study of Kaarakka et al. (2014), 10 years after the final whole-tree harvest it was evident that repeated whole tree harvest had a decreasing effect on total $\mathrm{C}$ and $\mathrm{N}$ pools. However, treatment did not have a significant effect on the ratio C/N (Kaarakka et al., 2014). In contrast, studies in Sweden and United States provided no evidence that whole tree harvesting reduced soil organic matter pools, C or N (Johnson et al., 1991; Olsson et al., 1996).

Generally, the global radiation in intervened/harvested forest stands was found to be 4 times higher, than in nonintervened ones. In addition, soil temperature in the upper $30 \mathrm{~cm}$ of mineral soils were higher in intervened, than in intact sites. The higher soil temperatures after forest harvesting usually enhance biological activity and, therefore, they also enhance the mineralization of soil organic matter and soil respiration (Caldentey et al., 2000). Higher respiration activity increases the release of $\mathrm{CO}_{2}$ to the atmosphere and consequently less organic $\mathrm{C}$ is stored in the organic layers and mineral soil. The difference between our results and those of other researchers (who found significant reductions of soil organic matter after forest harvesting) could be probably ascribed to the lower: i) mineralization rates of organic matter and ii) soil respiration, which probably occurred 5 and 15 years after harvesting. Organic matter accumulation in the disturbed forest sites was linearly decreased in the soil profile $0-50 \mathrm{~cm}$, and significant differences between the intact forest and the 15-year site were found; the same also happened for organic $\mathrm{N}$ accumulation (Table 2).

Exchangeable $\mathrm{Ca}$ concentrations decreased after selective harvesting, especially in the 15 -year treatment and in the upper $10 \mathrm{~cm}$ (Table 1). In addition, Ca accumulation was also significantly lower in the 15-year treatment, compared to the control site (Table 2). This probably happened due to the decrease of biomass (a significant amount of $\mathrm{Ca}$ is contained in trunk woods, which after removal is not available to forests). Saarsalmi et al. (2010) also found significantly lower exchangeable Ca concentrations as a result of tree harvesting in a Scotch pine stand. Insignificant difference in $\mathrm{pH}$ between the intact (control) site and the other two treatments was found in our study, which agrees with the data of Covelo and Gallardo (2002) for disturbed young oak trees, in NW Spain, after pine harvesting. Similarly, our data are also in agreement with those of Kaarakka et al. (2014) for Norway spruce after whole-tree harvesting. In addition, in the study of McGrath et al. (2001), 6 years after the establishment of an agroforest on initially forestlands, the concentrations of exchangeable base cations (especially $\mathrm{Ca}$ and $\mathrm{Mg}$ ), cation exchange capacity (C.E.C.) and $\mathrm{pH}$ were higher in agroforest soils, than in those of adjacent forests. In our study, higher $\mathrm{Mg}$ concentrations were found in the 5-year treatment, compared to the intact site, but insignificant differences were recorded between the 15-year treatment and the control site (Table 1). Similarly, Mg accumulation was significantly higher in the 5-year treatment (Table 2). The higher exchangeable Mg concentrations in the 5-year treatment could be attributed to enhanced weathering rates after canopy removal and rise of soil temperatures.

In contrast, significantly lower $\mathrm{K}$ and $\mathrm{Na}$ (in the upper soil layers, i.e. $0-5$ and $5-10 \mathrm{~cm}$ ) concentrations were found in the 5-year treatment (Table 1), compared to the other two managements, and this finding might be probably ascribed to the antagonism between $\mathrm{Mg}$, Ca and $\mathrm{K}, \mathrm{Na}$ for common C.E.C. sites, as well as to the enhanced $\mathrm{K}$ losses (there were probably reduced $\mathrm{K}$ recycling rates because of biomass decrease) during the first 5 years after selective tree harvesting. Fifteen years after harvesting, a restoration in $\mathrm{K}$ recycling rates possibly occurred due to canopy closure; this probably could explain why $\mathrm{K}$ concentrations in the upper soil layers $(0-5$ and $5-10 \mathrm{~cm})$ did not significantly differ between the control site and the 15-year treatment. The main path of $\mathrm{K}$ in forest ecosystems is through leaves' fall. As the canopy becomes denser, $\mathrm{K}$ concentrations usually increase due to enhanced recycling rates. In contrast to our results, in the study of Romanowicz et al. (1996) soil exchangeable $\mathrm{K}$ pools increased 3 years after whole-tree harvesting, at the Hubbard Brook experimental forest, and decreased after 8 years, remaining, however, $20 \%$ above preharvest pools. According to the same authors, the increased: i) $\mathrm{K}$ release from organic matter mineralization and ii) weathering were probably the responsible factors for the increase of $\mathrm{K}$ in the soil exchange complex. The difference between our results and those of Romanowicz et al. (1996) could be probably ascribed to the much lower organic C mineralization rate in our study.

Iron concentration in the upper soil layer $(0-5 \mathrm{~cm})$ of the control site was significantly lower, compared to the two treatments; however, Fe concentrations in soil depths 10-30 $\mathrm{cm}$ and $30-50 \mathrm{~cm}$ of the treated sites were significantly lower, compared to the intact site (Table 1). Copper concentrations in the soil layers $0-5,5-10$ and $10-30 \mathrm{~cm}$ were from 1.5 to 4 times lower in the disturbed forests, than in the intact site. Manganese and $\mathrm{Zn}$ concentrations were significantly lower in the 5- and 15-year treatments, compared to the intact site (Table 1). In the study of Gronflaten et al. (2008) it was found that two years after clear cutting, $\mathrm{Cu}, \mathrm{Mn}$ and $\mathrm{Zn}$ concentrations decreased in a coniferous forest soil of southern Sweden; according to their opinion, this probably happened due to increased soil $\mathrm{pH}$ (Gronflaten et al., 2008). In our study the significantly 
decreased soil $\mathrm{Mn}$ and $\mathrm{Zn}$ concentrations after forest harvesting was not due to increased $\mathrm{pH}$, since it did not significantly change after the disturbance (Table 1). The reduced micronutrient concentrations in the treated sites, compared to the intact forestland, could be probably attributed to the decreased amount of soil organic matter after harvesting.

The accumulation of most nutrients in forest floor significantly differed among the 3 treatments, with the exception of $\mathrm{Ca}$ (Table 4). The highest organic matter accumulation was recorded in the 15-year treatment. The lowest $\mathrm{N}, \mathrm{P}, \mathrm{Mg}, \mathrm{K}, \mathrm{Fe}, \mathrm{Cu}$ and $\mathrm{Mn}$ accumulation was observed in the 5-year treatment (Table 4), which means that 5 years after the selective harvesting reduced nutrient recycling rates (due to decreased forest biomass), together with enhanced leaching and increased runoff (loss of forest floor) were probably the responsible factors for the lowest nutrient accumulation. In contrast, the restoration of ecosystem equilibrium 15 years after selective harvesting leaded to similar or even higher organic $\mathrm{C}$ and nutrient accumulation in forest floor in the 15-year treatment, compared to the control site (Tables 3 and 4). Gronflaten $e t$ al. (2008) found higher $\mathrm{Mn}$ and $\mathrm{Zn}$ concentrations in the humus layer two years after conventional tree cutting, compared to whole tree clear cutting.

With regard to foliar nutrient concentrations, significant differences between the three experimental sites were found only for $\mathrm{Fe}, \mathrm{Zn}$ and $\mathrm{K}$ (Table 5). Zinc concentration was significantly higher in the intact sites, compared to the 15-year treatment, while the maximum foliar $\mathrm{K}$ and $\mathrm{Fe}$ concentrations were found in the 5-year treatment (Table 5). In the study of Covelo and Gallardo (2002), foliar N concentration was $20 \%$ higher at the undisturbed sites, but pine harvesting did not modify leaf $\mathrm{P}$ concentration.

Some authors demonstrated that the N/P ratio is a reliable indicator of nutrient limitation by $\mathrm{N}$ or $\mathrm{P}$, where there is no other limiting factor. In a variety of plant communities, they found that a value of the N/P ratio in plant tissue higher than 16 is indicative of $\mathrm{P}$ limitation (Koerselman and Meuleman, 1996; Verhoeven et al., 1996). According to Covelo and Gallardo (2002), the values of the leaf ratio N/P in their study was about 20 in the control sites and 17 in the harvested sites, suggesting $P$ limitation in both of them. In contrast, in our case N/P values among the three treatments varied from approximately 12 to a little less than 15 (Fig. 2), i.e. it was lower than 16 reported by Covelo and Gallardo (2002). Thus, no P limitation occurred in our study. The differences between our results and those of Covelo and Gallardo (2002) could be probably ascribed to the different forest species between the two areas of experimentation (Picea abies plantations in our case, and Pinus pinaster plantations in the study of Covelo and Gallardo, 2002), and/or to the differential soil chemical properties between the two experimental sites.

\section{Conclusions}

All the significant differences in chemical properties among the three treatments were basically distinct in the upper $30 \mathrm{~cm}$ of soil profiles. From all the results, it is concluded that forest management practices clearly influenced soil nutrient availability and organic matter accumulation. More specifically, in most cases, higher nutrient concentrations and accumulation in soil and forest floor were found in the $15 \mathrm{Y}$, than in the $5 \mathrm{Y}$ treatment. This result could be probably attributed to enhanced nutrient recycling rates in the $15 \mathrm{Y}$ treatment (due to increase of forest biomass 15 years after harvesting), as well as to increased forest floor losses due to increased surface runoff 5 years after selective cutting (because of canopy opening). Thus, our hypothesis that 15 years after selective harvesting the increased forest biomass, together with the enhanced nutrient recycling rates (compared to the 5 -year treatment) could restore nutrient availability and organic C accumulation to similar levels to those of the intact sites, was partially correct. This was clearly evident for nutrient and organic $\mathrm{C}$ accumulation in forest floor, as well as for $\mathrm{K}$ and Fe accumulation in soil.

\section{References}

Allen SE, Grimshaw, HM, Rowland AP (1986). Chemical analysis. In: Moore PD, Chapman SB (Eds). Methods in Plant Ecology. Blackwell Scientific Publication, Oxford, London pp 285-344.

Alifragis D (2010). Description, sampling, laboratory analyses of forest soils and plant tissues. Aivazis Press, Thessaloniki, Greece (in Greek).

Allison LE (1965). Organic matter. In: Black CA (Ed). Methods of Soil Analysis. American Society Agronomy Inc Publications, Vol 2, Madison pp 1367-1378.

Bartsch N (2000). Element release in beech (Fagus sylvatica L) forest gaps. Water Air and Soil Pollution 122:3-16.

Bates RG (1964). Determination of pH. Theory and Practice. John Wiley and Sons, New York.

Caldentey J, Promis A, Schmidt H, Ibarra M (2000). Variation microdimatica causada por una corte de proteccion en un bosque de Lenga (Nothofaguspumilio). Ciencias Forestales 14:52-59.

Cerda A, Lucas Borja ME, Ubeda X, Martinez-Murillo JF, Keesstra S (2017). Pinus halepensis M. versus Querus ilex subsp. Rotundifolia L. runoff and soil erosion at pedon scale under natural rainfall in Eastern Spain three decades after a forest fire. Forest Ecology and Management 400:447-456.

Covelo F, Gallardo A (2002). Effect of pine harvesting on leaf nutrient dynamics in young oak trees at NW Spain. Forest Ecology and Management 167: 161-172.

Dilustro JJ, Collins B, Duncan L, Crawford C (2005). Moisture and soil texture effects on soil $\mathrm{CO}_{2}$ efflux components in southeastern mixed pine forests. Forest Ecology and Management 204:87-97.

Dirham RK (1998). Altered leaf-litter decomposition rates in tropical forest fragments. Oecologia 116:397-406.

Grant EG (1982). Exchangeable cations. In: Page AL (Ed). Methods of Soil Analysis, Part 2. American Society of Agronomy and Soil Science Society of America, Madison, Wisconsin, USA pp 159-164.

Gronflaten LK, Steinnes E, Orlander G (2008). Effect of conventional and whole-tree clear-cutting on concentrations of some micronutrients in coniferous forest soil and plants. Forestry Studies 48:5-16.

Herbohn JL, Congdon RA (1998). Ecosystem dynamics at disturbed and undisturbed sites in North Queensland wet tropical rain forest. III. Nutrient returns to the forest floor through litterfall. Journal of Tropical Ecology 14:217-229. 
308

Johnson CE, Johnson AH, Huntington TG, Siccama TG (1991). Wholetree clear cutting effects on soil horizons and organic matter pools. Soil Science Society for the America Journal 55:497-502.

Johnson DW, Curtis PS (2001). Effects of forest management on soil C and N storage: meta analysis. Forest Ecology and Management 140:227238.

Johnson DW, Knoepp JD, Swank WT, Shan J, Morris LA, Van Lear DH, Kapeluck PR (2002). Effects of forest management on soil carbon: results of some long-term resampling studies. Environmental Pollution 116:201-208.

KaarakkaL, Tamminen P, Saarsalmi A, Kukkola M, HelmisaariHS, Burton AJ (2014). Effects of repeated whole-tree harvesting on soil properties and tree growth in a Norway spruce (Picea abies (L.) Karst) stand. Forest Ecology and Management 313:180-187.

Klein D, Fuentes JP, Schmidt A, Schmidt H, Schulte A (2008). Organic C as affected by silvicultural and exploitative interventions in Nothofagus pumilio forests of the Chilean Patagonia. Forest Ecology and Management 255:3549-3555.

Knoepp JD, Swank WT (1997). Forest management effects on surface soil carbon and nitrogen. Soil Science Society of the America Journal 61:928-935.

Koerselman W, Meuleman AFM (1996). The vegetation N:P ratio: a new tool to detect the nature of nutrient limitation. Journal of Applied Ecology 33:1441-1450.

Laiho R, Sanchez F, Tiarks A, Dougherty PM, Trettin CC (2003). Impacts of intensive on early rotation trends in site carbon pools in the southeastern US. Forest Ecology and Management 174:177-189.

Lal R (2005). Forest soils and carbon sequestration. Forest Ecology and Management 220:242-258.

Lindenmayer DB, Franklin JF (2002). Conserving forest biodiversity: A comprehensive multiscaled approach. Island Press, Washington, USA.

Lindsay WL, Norvell WA (1978). Development of a DTPA soil test for zinc, iron, manganese and copper. Soil Science Society of the America Journal 42:421-428.

Mataix-Solera J, Cerda A, Arcenegui V, Jordan A, Zavala LM (2011). Fire effects on soil aggregation: A review. Earth-Science Reviews 109:44-60.

Mauromatis GN (1980). Bio-dimate of Greece. Bioclimatic Maps. Forest Research I(Appendix) (in Greek).

McGrath DA, Duryea ML, Cropper WP (2001). Soil phosphorus availability and fine root proliferation in Amazonian agroforests 6 years following forest conversion. Agriculture Ecosystems and Environment 83:271-284.

McLaughlin JW, Phillips SA (2006). Soil carbon, nitrogen, and base cation cycling 17 years after whole-tree harvesting in a low-elevation red spruce (Picea mbens) - balsam fir (Abies balsamea) forested watershed in central Maine, USA. ForestEcology and Management 222:234253.

McLean EO (1982). Soil pH and Rime requirement. In: Page AL (Ed). Methods of Soil Analysis, Part 2. American Society of Agronomy and Soil ScienceSociety of America, Madison, Wisconsin, USA pp 199-223.

Mendham DS, O'Conell AM, Grove TS, Rance SJ (2003). Residue management effects on soil carbon nutrient contents and growth of second rotation eucalyptus. Forest Ecology and Management 181:357372.
Merino A, Fernandez-Lopez A, Solla-Gullon F, Edeso JM (2004). Soil changes and tree growth in intensively managed radiata pine plantations in Northern Spain. Forest Ecology and Management 196:393-404.

Nelson DW, Sommers LE (1982). Total carbon, organic carbon and organic matter. In: Page AL (Ed). Methods of Soil Analysis, Part 2. American Society of Agronomy and Soil Science Society of America, Madison, Wisconsin, USA pp 539-577.

Olsen SR, Sommers LE (1982). Phosphorus. In: Page AL (Ed). Methods of Soil Analysis, Part 2. American Society of Agronomy and Soil Science Society of America, Madison, Wisconsin, USA pp 403-427.

Olsson BA, Staaf H, Lundkvist H, Bengtsson J, Rosen K (1996). Carbon and nitrogen in coniferous forest soils after clear-felling and harvests of different intensity. Forest Ecology and Management 82:19-32.

Papaioannou A, Chatzistathis T, Papaioannou E, Papadopoulos G (2016). Robiniapsendoacacia $\mathrm{L}$. as a valuable invasive species for the restoration of degraded croplands. Catena 137:310-317.

Peltoniemi M, Mäkipää R, Liski J, Tamminen P (2004). Changes in soil carbon with stand age - an elevation of a modelling method with empirical data. Global Change Biology 10:2078-2091.

Pereira P, Cerda A, Martin D, Ubeda X, Depellegrin D, Novara A, ... Miesel J (2017). Short-term low-severity spring grassland fire impacts on soil extractable elements and soil ratios in Lithuania. Science of the Total Environment 578:469-475.

Rodrigo Comino J, Brings C, Lassu T, Iserloh T, Senciales JM, Martinez Murillo JF, ... Ries JB (2015). Rainfall and human activity impacts on soil losses and rill erosion in vineyards (Ruwer valley, Germany). Solid Earth 6:823-837.

Rodrigo Comino J, Senciales JM, Ramos MC, Martinez-Casasnovas JA, Lasanta T, Brevik EC, ... Ruiz Sinoga JD (2017). Understanding soil erosion processes in Mediterranean sloping vineyards (Montes de Malaga, Spain). Geoderma296:47-59.

Romanowicz RB, Driscoll CT, Johnson CE, Fahey TJ, Likens GE, Siccama TG (1996). Changes in the biogeochemistry of K following a whole-tree harvest. Soil Science Society of the America Journal 60: 16641674.

Saarsalmi A, Tamminen P, Kukkola M, Hautajarvi R (2010). Whole-tree harvesting at clear felling: impact on soil chemistry, needle nutrient concentrations and growth of Scots pine. Scandinavian Journal of Forest Research 25:148-156.

Stevenson FJ (1982). Nitrogen-Organic forms. In: Page AL (Ed). Methods of Soil Analysis, Part 2. American Society of Agronomy and Soil Science Society of America, Madison, Wisconsin, USA pp 625-641.

Verhoeven JTA, Koerselman W, Meuleman AFM (1996). Nitrogen or phosphorus-limited growth in herbaceous, wet vegetation: relations with atmospheric inputs and management regimes. Trends in Ecology andEvolution 11:494497.

Vande Walle I, Mussche S, Samson R, Lust N, Lemeur R (2001). The above- and belowground carbon pools of two mixed deciduous forest stands located in East-Flanders (Belgium). Annals of Forest Science 58:507-517. 